\title{
Crustal Shear Zones in Central Africa: a Kinematic Approach to Proterozoic Tectonics
}

\section{by Michael C. Daly}

An understanding of the displacement patterns (kinematics) of orogenic belts is essential in order to analyze complex regional structural relationships and the tectonic processes involved. This article outlines some results from kinematic studies carried out during the past decade on shear and thrust zones associated with Proterozoic orogenic belts in Central Africa. These data indicate that Proterozoic orogeny is characterized by major horizontal displacements and that previous ideas of dominantly vertical tectonics are not supported.

\section{Shear Zones and Tectonics}

Shear zones are one of the most prominent deformation features of orogenic belts, both in the Phanerozoic and Precambrian. In many places they define the major boundaries of deeply eroded orogenic belts, as well as zones of more intense deformation within them. Crustal plates or terranes may thus appear as discrete geological units bounded by high strain shear zones, the displacement along which may be of dip, oblique or strike-slip type. The nature of these bounding shear zones is useful in constraining the kinematic evolution of very complex orogenic terranes. With such data a beginning can be made in modelling the tectonic processes that fashioned Precambrian and Phanerozoic orogenic belts, in addition to the more classical approaches to orogenic analysis using regional cross-cutting relationships and radiometric dating pioneered by Holmes (1951) and Cahen and others (1984).

Central Africa contains a large number of shear zones that range widely in size and image. They formed at a variety of crustal levels and differ greatly in their tectonic significance and displacement pattern. There has been considerable debate as to the role of large horizontal displacements in the formation of the complex network of African orogenic belts. Reports of very little offset of pre-existing structures across the Zambezi, Kibaran and Irumide Proterozoic orogenic belts in Central Africa (Shackleton, 1973), and apparently supporting paleomagnetic evidence (Briden, 1976), led to orogenic models involving vertical tectonics (Kröner, 1977).

It was with the airh of providing some kinematic constraints on these models that the work summarized here was undertaken. This article discusses concepts of orogenic kinematics and outlines the tectonic setting and kinematic patterns of three regional shear zones exposed in Zambia, Zimbabwe, Malawi and Tanzania.

\section{Orogenic Kinematics}

The shear zones that bound many orogenic belts appear analogous in geometry to higher level structures developed in thin-skinned thrust zones. Contemporary concepts of thrust tectonics have developed from foreland thrust belts

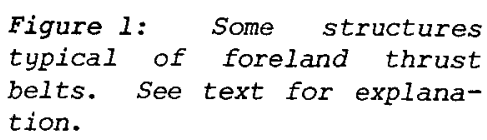

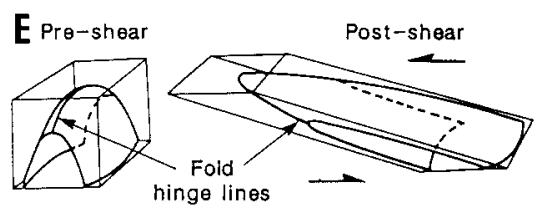

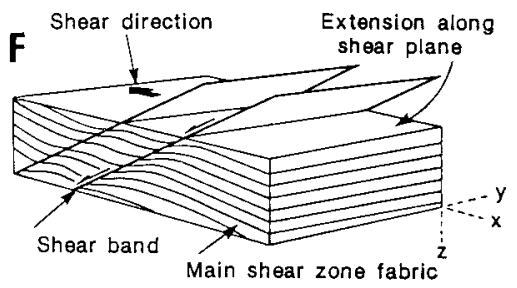


such as the Rocky Mountains and are based on field, well, and seismic reflection data (Bally et al., 1966; Dahlstrom, 1970; Boyer and Elliott, 1982).

Thrusts are compressional structures that shorten and thicken strata, characteristically duplicating beds and cutting-up section in the direction of movement. In wellbedded rocks, thrusts often follow a staircase trajectory, developing flats parallel to bedding in easy slip horizons, but climbing ramps across the bedding in more competent rocks. These ramp structures transfer displacement between easy slip horizons and may strike normal (frontal ramp), parallel (lateral ramp), or obliquely (oblique ramp) to the thrust transport direction (Fig. 1A).

A single ramp structure has a potential transport direction contained within a $180^{\circ}$ arc. Thus, the recognition of several ramp orientations will allow the constraining of thrust transport direction (Fig. 1B). In front of and above frontal and oblique ramps, beds are duplicated and the overlying strata are bulged up into an antiformal structure. Where the ramp development is irregular the thrust profile may appear corrugated in sections normal to the transport direction. This leads to the development of a series of broad, flat-topped anticlines offset across the lateral ramps, resulting in a series of culminations and depressions (Fig. 1C, after Dahlstrom, 1970).

A geometry similar to that of foreland thrust zones may be detected in the more ductile regime of the middle and lower crust. Deep displacement zones developing as broad ductile shear zones occur frequently in the basement gneiss terranes of Africa. These shear zones are characterized by grain-size reduction, mylonitic foliation and a well developed preferred orientation of minerals. Figure 2 shows the type of rock fabrics found in shear zones from the Irumide belt of Zambia, which are typical of the structures discussed here. The montage shows an undeformed porphyritic granite (Fig. 2A) and its highly sheared equivalent in a major shear zone. Figure 2B shows a well-developed mylonitic foliation and smeared-out porphyroclasts, and Figure $2 \mathrm{C}$ a foliation surface, which contains a strong mineral lineation thought to define the displacement direction during shearing. The photomicrograph (Fig. 2D) shows both brittle and ductile deformation features within these shear zones, where brittle fracturing of feldspar porphy roclasts has occurred.

Figure 2: Rock fabrics in the Irumide belt of zambia. $D$ is $2 \mathrm{~cm}$ wide. See text for explanation.

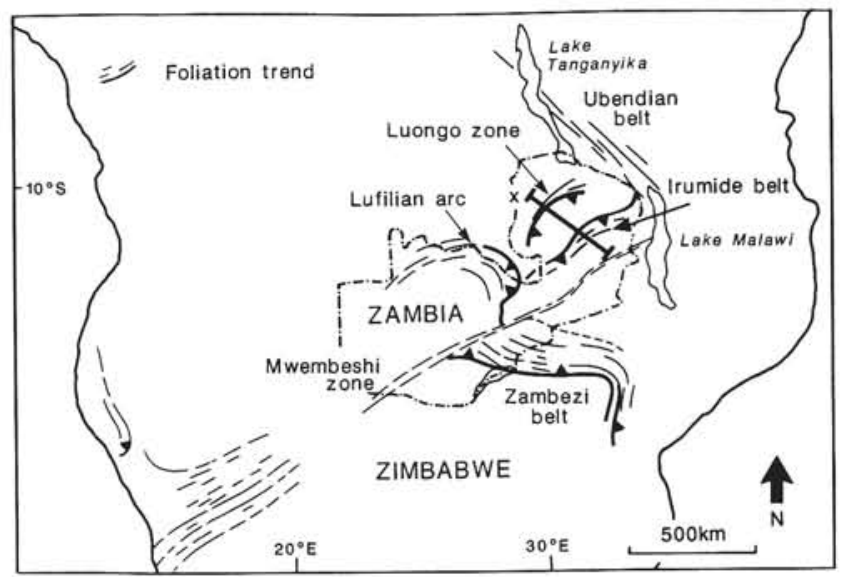

Figure 3: Shear zones of Central Africa, showing the location of the cross section shown in Figure 7.

The shear zones may be associated with dip, oblique or strike-slip displacements and vary in attitude from flat to vertical. They approximate in their deformation mechanism to zones of simple shear (Ramsay, 1980), in which the initial planar deformation fabric develops at $45^{\circ}$ to the shear plane. With increasing shear strain (shown by the solid ellipses in Fig. 1D) this fabric rotates into parallelism with the shear plane. Similarly, the extension direction (X), marked as a linear mineral fabric on the resultant foliation, rotates towards parallelism with the movement direction in the shear plane. This fabric results in the typical L-S mylonitic fabrics that characterize major shear zones. Any passive markers, such as pre-existing fold structures, will rotate towards this bulk transport direction with increasing strain. The rotation may result in folds (Fig. 1E) with curvilinear fold hinge lines of sheath-like geometry (Cobbold and Quinquis, 1980).

Shear zones often develop secondary shears at an oblique angle to the main foliation, but with the same movement sense (Fig. 1F). These secondary features have the effect of extending the shear zone and have been variously described as an extensional crenulation cleavage (Platt and Vissers, 1980) or shear bands (White et al., 1986). They may appear as both brittle or ductile features and characteristically occur perpendicular to the extension lineation. They
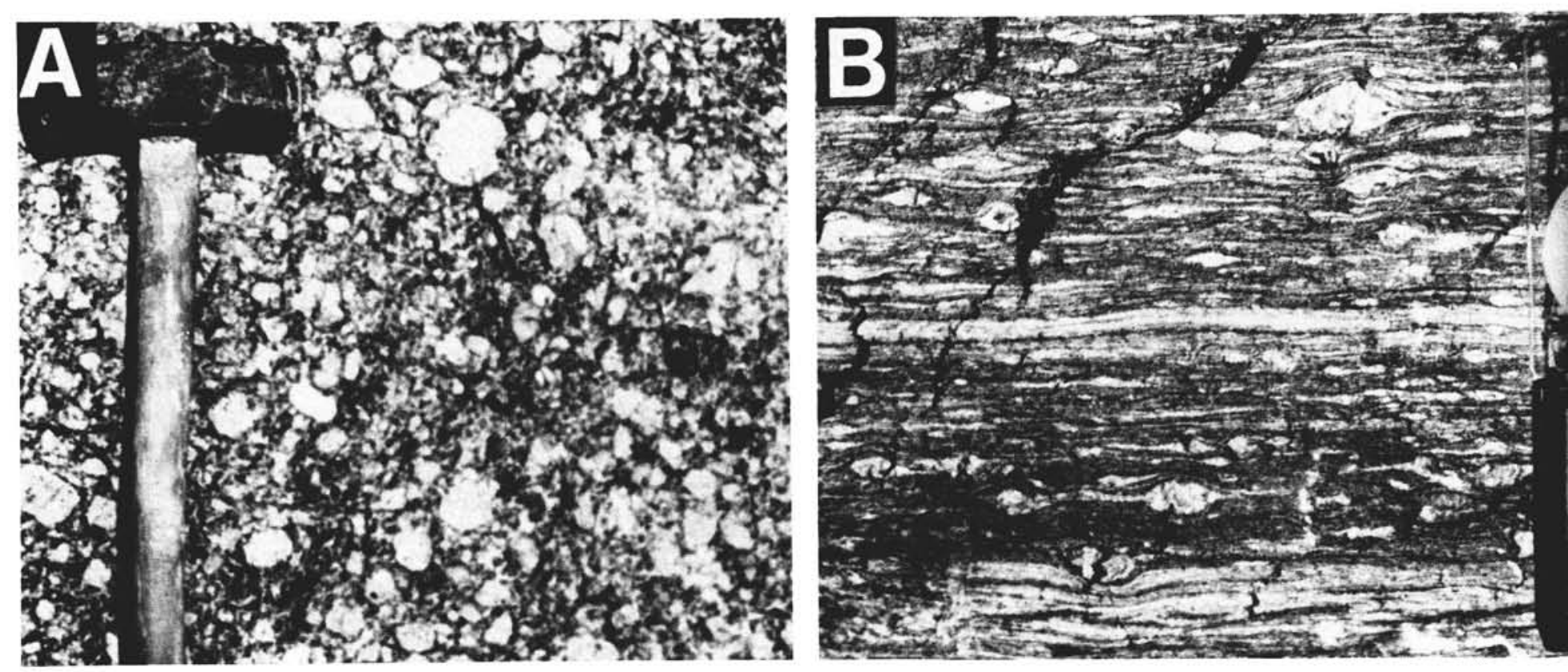


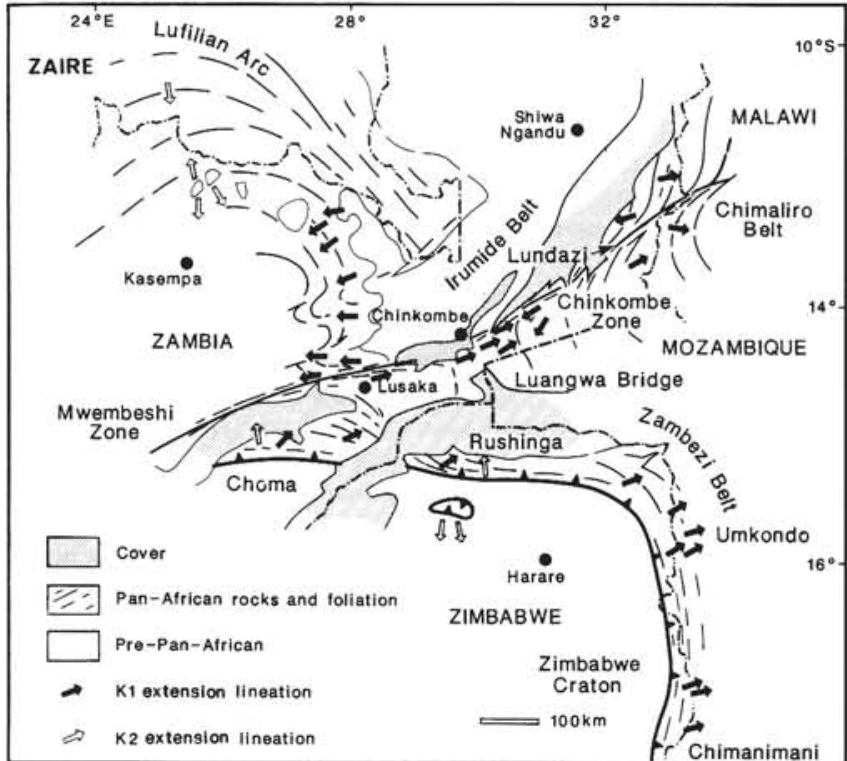

Figure 4: Sketch map of the Mwembeshi shear zone and associated thrust belts showing the distribution of stretching (extension) lineations.

are thus useful as displacement indicators and also demonstrate shear sense. A range of other meso- and microscopic indicators in sheared rocks have been discussed by White and others (1986). These shear sense indicators, however, may only reflect a part of the strain path, and the gross geometric effects of the shear zone (i.e. crustal thickening, crustal thinning or lateral translation) must also be considered when assessing its tectonic significance.

From the criteria outlined, the tectonic transport direction of both high-level, foreland thrust belts and middle to lower crustal shear zones can be determined and their kinematic relationships deduced. The orientation of lateral ramps and tear faults, developed at all crustal levels, are probably the most reliable indicators of displacement direction. Linear fabrics of shear zones may be affected by pre-existing fabrics and local perturbations in the strain pattern, but a test of their reliability lies in their regional consistency.
The examples that follow rely on both regionally consistent extension lineations and lateral ramp structures to deduce the displacements outlined.

The Mwembeshi: A Transform Shear Zone

A major crustal seale shear zone transects Central Africa (Daly, 1986a). The central part of this ENE-trending zone is known as the Mwembeshi Dislocation Zone (de Swardt et al., 1965), which occurs between the two Late Proterozoic orogenic belts of the Lufilian are and Zambezi belt (Fig. 3). Several other dislocations, involving both lateral and vertical displacements are associated with the Mwembeshi zone. The tectonics and relative age of these thrust belts have been discussed elsewhere (Daly et al., 1984; Coward and Daly, 1984; Daly, 1986a) and will only be summarized here.

The Lufilian arc comprises the copper bearing sedimentary rocks of the Katangan Supergroup. These have been folded and thrust to define a major arcuate structure, largely inherited from the original Katangan basin morphology. In the southeast part of this arc the majority of the structures face ENE, and the rocks are of low metamorphic grade. Thrust geometries define a number of ENE-trending lateral ramp and culmination structures, whereas basement shear zones are characterized by a SW to WSW-plunging linear fabric (Fig. 4). These features indicate an ENE tectonic transport direction for the main Copperbelt structures.

To the south of the Copperbelt a series of shear zones are developed at a high angle to the trend of the arcuate thrust belt. In this region the sole thrust of the Lufilian thrust system appears to have climbed section to the base of the Katangan meta-sediments (Coward and Daly, 1984). Here the Katangan basement contact is intensely deformed and has clearly been a significant movement zone. Southwards, the Lufilian arc terminates against the Mwembeshi zone.

The Zambezi belt lies to the south of the Lufilian arc and is separated from it by the Mwembeshi Zone. The Zambezi structures face to the SW and SSW (Fig. 4) and involve deep crustal metamorphic rocks with high pressure mineral assemblages (Barr, 1974) and eclogitic intrusions (Vrana et al., 1975). Despite their dissimilarity in metamorphic grade, the meta-sediments of the Zambezi belt have been correlated on lithostratigraphic grounds with the lower grade Katangan sediments of the Lufilian are (Smith, 1963).

The SW and southern boundary of the Zambezi belt is a major shear zone that imbricates Mid-Late Proterozoic metasedimentary sequences with Proterozoic and Archaean basement gneisses of the Zimbabwe craton. To the east, the
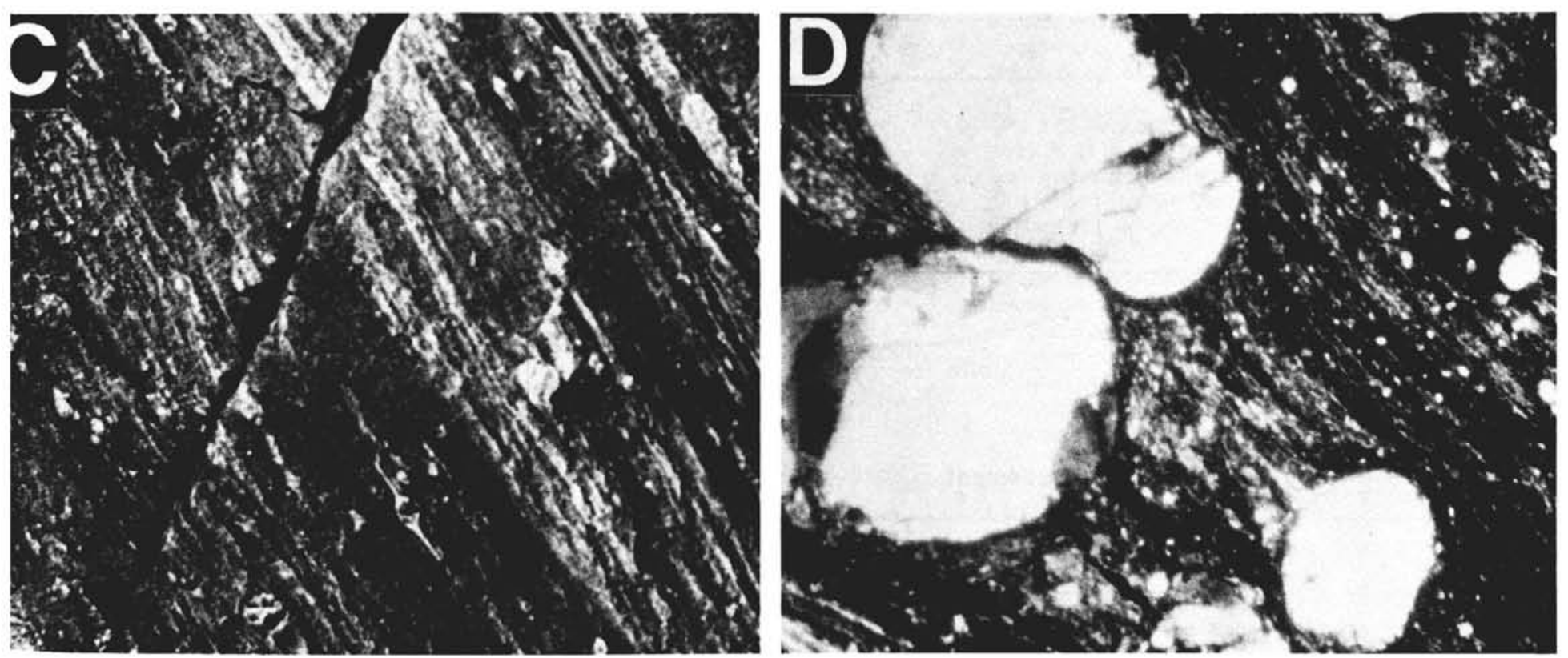


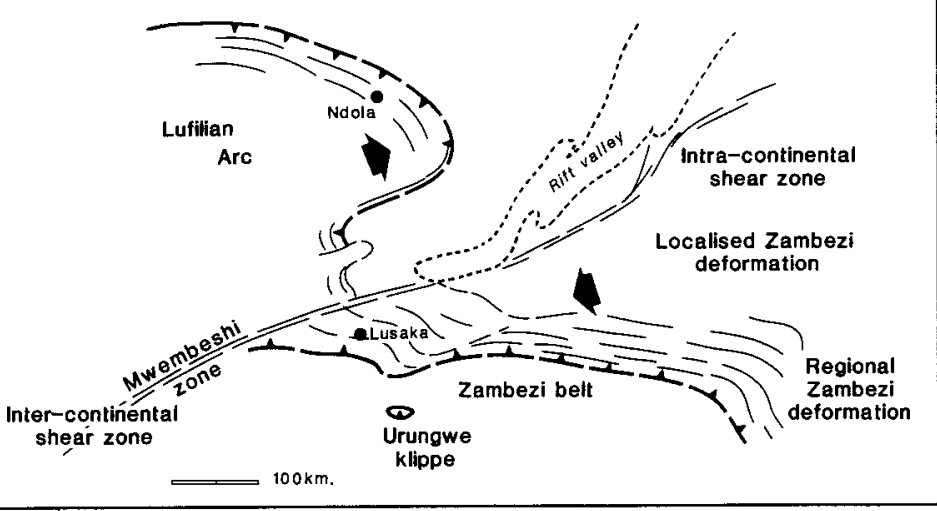

Figure 5: Tectonic setting of the Mwembeshi shear zone, associated thrust belts and intra-continental splays.

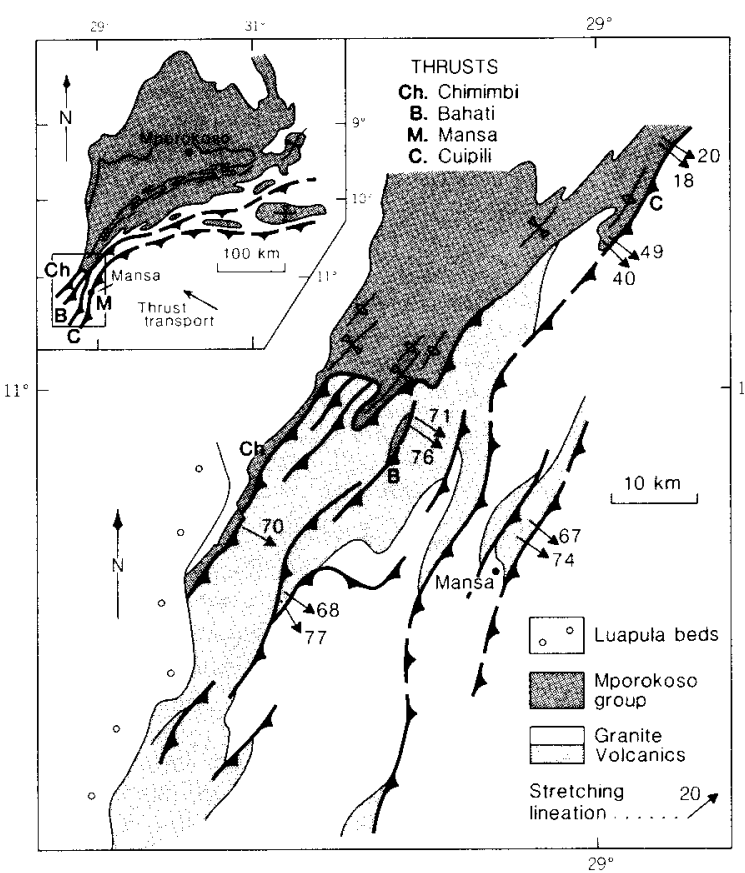

Figure 6: The Luongo shear zone. The main portion shows the distribution of the major thrusts and linear fabrics in the southern part of the shear zones front of the Zambezi belt swings southwards to define the northerly trending, eastern edge of the Zimbabwe craton. A low-grade metasedimentary sequence known as the Umkondo Group is preserved here in the frontal part of the belt. From thrust geometry and stretching lineations (Fig. 4) in low-grade mylonite zones it is apparent that these sediments were thrust to the WSW over the Archean craton.

In the east-west part of the Zambezi belt, extension lineations and thrust geometries indicate two directions of tectonic transport: an early WSW-directed thrusting followed by, or broadly contemporaneous with, a southerly directed event. Figure 4 shows the added complexity of the north-plunging lineations in the east-west arm of the Zambezi belt and the northern part of the Lufilian are. Daly (1986a) interpreted the two distinct lineation directions as representing two separate kinematic events: Kl (ENE-WSW directed) and $\mathrm{K} 2$ (north-south directed). However, the sequential development of the two orientations is not proven, and a coeval relationship with two displacement components (WSW and north-south) of a single transpressive deformation is also possible.

The Mwembeshi Zone marks the boundary between the Lufilian arc and Zambezi belt (Figs. 4, 5), trending approximately ENE/WSW. In the west it is a $10 \mathrm{~km}$-wide shear zone, and eastwards the zone passes below the Luano rift and is correlated with the Ilinda and Chinkombe shear zones of the eastern Zambia and the Chimaliro belt of Malawi (Daly, 1986b).

The deformation fabries within the $M$ wembeshi zone have a sub-horizontal, ENE or WSW-plunging extension lineation, indicating a similar tectonic transport direction to both the Lufilian (ENE-directed) and Zambezi (WSW-directed) deformations. The deformation fabric of the Zambezi belt swings into the Mwembeshi zone, maintaining the consistent lineation trend. These features suggest that the Lufilian arc, Zambezi belt and Mwembeshi zone are coeval and kinematically equivalent structures. Thus, the Mwembeshi zone acted as a major continental transform for the opposed thrust belts of the Lufilian and Zambezi. Coward and Daly (1984) suggested that this transform represented the boundary between the Congo and Kalahari plates.

The eastward continuation of the Mwembeshi zone is also mylonitic and characterized by dominantly ENE-WSW plunging linear fabrics (Hickman, 1978). However, here the

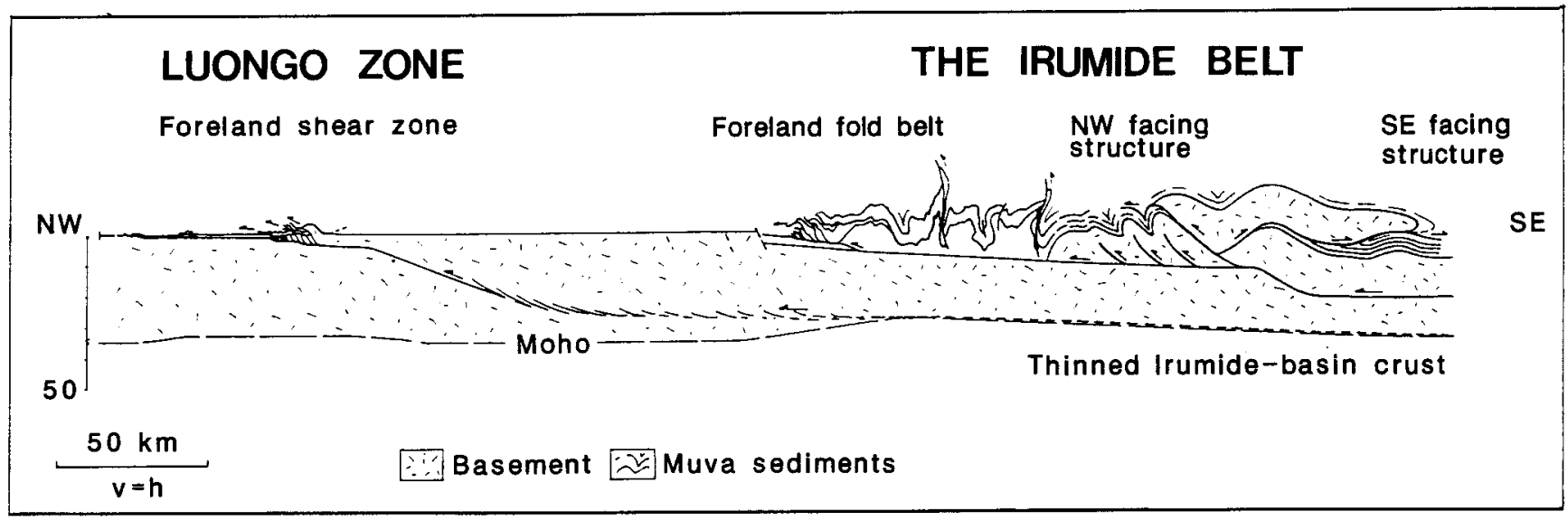

Figure 7: Regional cross section showing the proposed tectonic setting of the Luongo shear zone linked to the foreland fold and thrust belt of the Irumide belt. Section is located on Figure 3. 
zone is one of a series of late to post-Irumide shear zones of dextral strike-slip displacement and is not thought to represent a major plate boundary. This intra-continental continuation, or splay, links into the Mwembeshi zone in the area of the Luano rift valley (Fig. 5). An implication of the intra-continental and inter-continental nature of the Mwembeshi and associated shear zones is that the CongoKalahari plate boundary must diverge eastwards from the Mwembeshi zone. The location of this boundary is uncertain, but it must lie somewhere within the penetrative deformation zone of the Zambezi belt.

Clearly, therefore, an understanding of the kinematic evolution of the Late Proterozoic orogenic belts and shear zones in Central Africa clarifies the regional structural relationships of orogenic belts of widely differing trends and metamorphic grade. With such an internally consistent kinematic model it is now possible to incorporate other geological data and begin to understand the tectonic processes that fashioned these complex Proterozoic terranes. Importantly, the regionally consistent horizontal movement indicators show that the Late Proterozoic tectonics of Central Africa were dominated by horizontal displacements as opposed to previous models that favoured vertical tectonics (Kröner, 1977).

The Luongo Zone: A Discrete Foreland Shear Zone

A discrete, arcuate shear zone occurs in the Bangweulu Block of Zambia (Fig. 3), foreland to the Irumide orogenic belt (Daly, 1986b). The shear zone is exposed in the south as a series of steep, NNE-striking, brittle to ductile shears, which imbricate the basement granite and volcanics (Fig. 6). To the north, this narrow zone of foreland deformation folds and thrusts a series of ivid-Proterozoic cover quartzites, the Mporokoso Group. Locally, the basement is thrust over the quartzites and major recumbent folding marks the eastern-most basement cover contact.

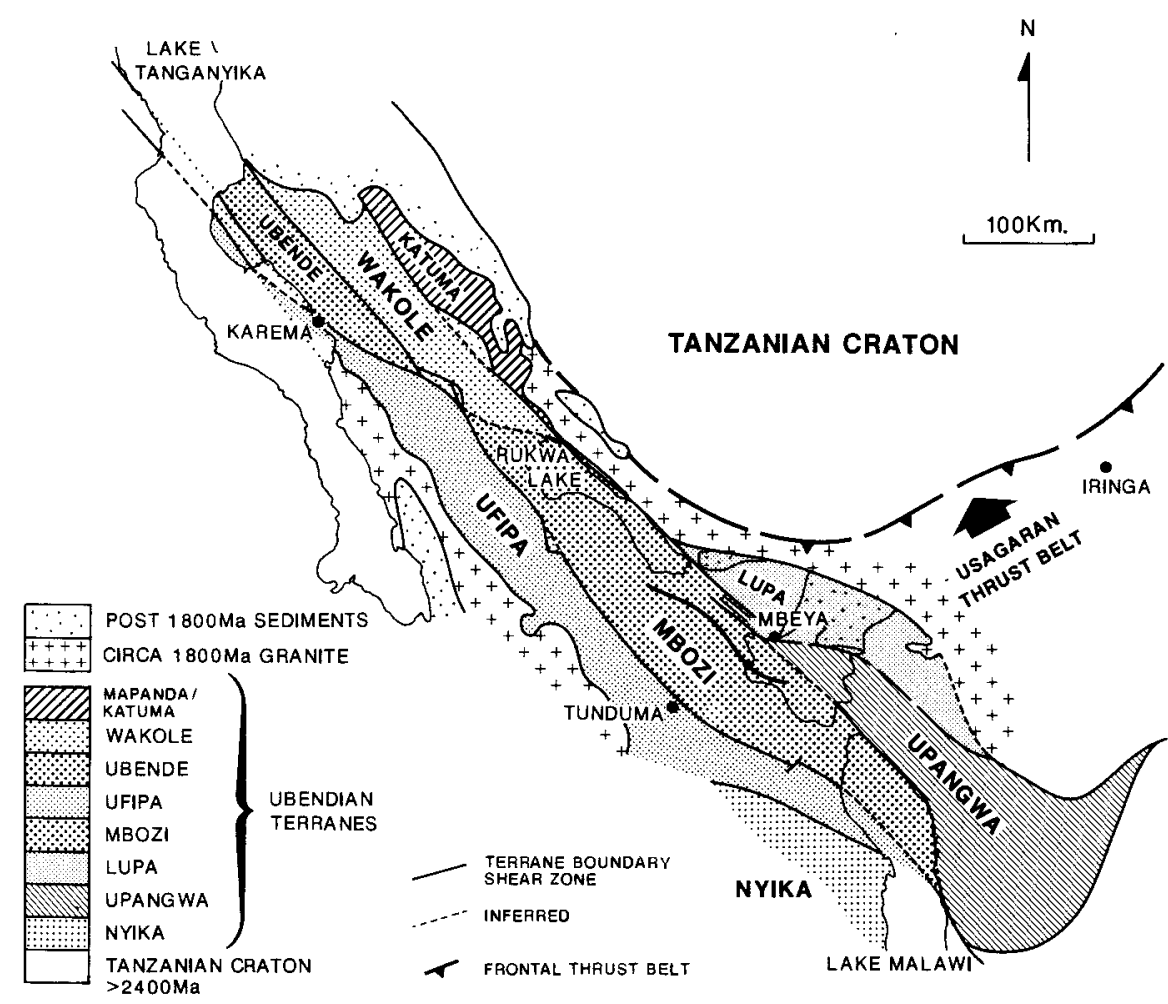

\begin{tabular}{|c|c|c|}
\hline TERRANE & $\begin{array}{l}\text { DOMINANT } \\
\text { LITHOLOGY }\end{array}$ & $\begin{array}{l}\text { LINEATION } \\
\text { TREND }\end{array}$ \\
\hline Upang wa & Meta-anorthosite & $\mathrm{NW}-\mathrm{SE}$ \\
\hline Mbozi & $\begin{array}{l}\text { Meta-basites and intermediate } \\
\text { granulites with quartzites }\end{array}$ & NE-SW \\
\hline Lupa & Meta-volcanics & No data \\
\hline Ufipa & Gneissic granite & $N W-S E$ \\
\hline Nyika & Cordierite granulites & $E-W$ \\
\hline Ubende & Meta-basites & ENE-WSW \\
\hline Wakole & Alumino-silicate schists & None \\
\hline
\end{tabular}

TABLE 1: Dominant lithologies of the Ubendian terranes and the regional trend of their mineral extension lineations

Within the mylonitic basement shear zones and the intensely deformed zones of the sediments, a strong $L-S$ fabric occurs, generally dipping to the ESE to SE. The linear element of this fabric is a down-dip stretching lineation, which together with the $N W$ to $W$-vergence of the folded and thrust quartzites indicates tectonic transport was directed approximately northwestwards. A similar displacement direction is obtained if one applies to the arc as a whole the bow and arrow rule of Elliott (1976), which states that the bisector of a simple thrust belt arc is parallel to regional displacement.

: The displacement on this shear zone suggests a kinematic relationship between the shear zone and the $\mathrm{NW}$-directed fold and thrust belt of the Irumide belt, some $200 \mathrm{~km}$ to the southeast. A coeval relationship is also supported by $\mathrm{K} / \mathrm{Ar}$ determinations carried out on biotite from within the Luongo shear zone, the undeformed Bangweulu Block and the Irumide belt (Daly 1986b). Similar dates around $1000 \mathrm{Ma}$ were obtained from both the Luongo shear zone and the Irumide Belt, indicating that both had a similar cooling age. However, the undeformed Bangweulu Block retained older, Early Proterozoic dates.

The similar thrust kinematics and age of cooling lead to the interpretation that the Luongo zone and the Irumide Belt form part of a linked thrust system, activated during the crustal shortening recorded in the Irumide Belt, as shown in Figure 7. Understanding the direction of tectonic transport associated with the deformation of the Luongo shear zone constrains the regional orogenic relationships of this isolated shear zone and demonstrates its association to horizontal tectonics and regional crustal shortening during the Late Proterozoic, in contrast again to the ideas of no crustal shortening previously popularized for the Irumide belt.

Figure 8 Sketch map of the Ubendian terranes and

their bounding shear zones. 


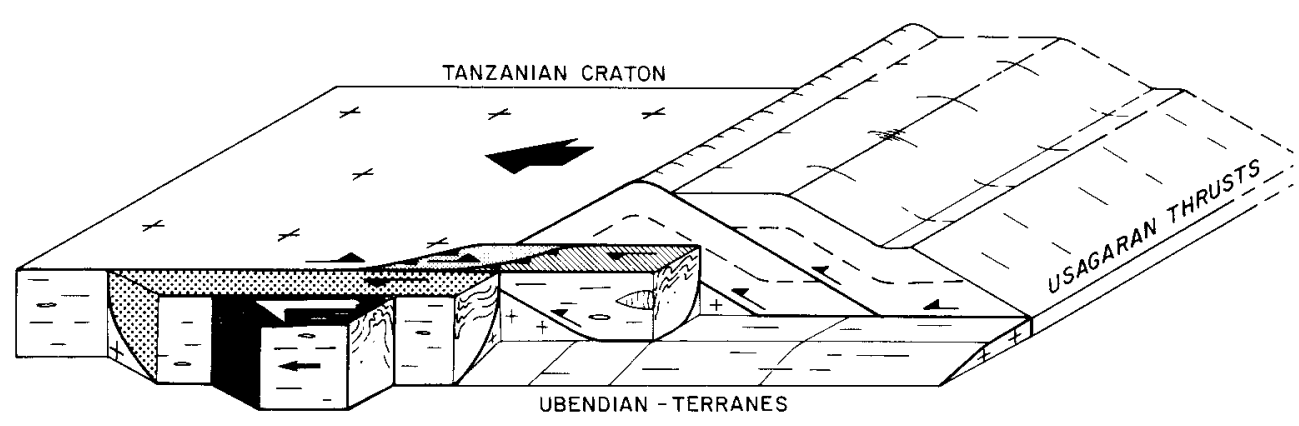

shear zones are often difficult to interpret because of later reactivation. They do have a consistent sub-horizontal plunge, but it is rarely possible to be certain as to which deformation this reflects.

Figure 9 presents a tectonic model for the juxtaposition of the Ubendian terranes. It suggests the terranes were accreted adjacent to the Tanzanian craton during the Early Proterozoic

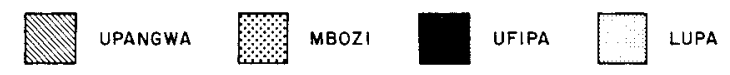

Figure 9: Tectonic model for the evolution of the ubendian belt terranes. Shear zone fabrics are shown schematically on the steep margins of the terranes.

\section{The Ubendian Belt: Shear Zones and Accreted Terranes}

The Ubendian belt is a Late Archaean-Early Proterozoic orogenic belt that defines the $S W$ margin of the Archaean Tanzanian craton (Fig. 4). MeConnell (1950) recognized a series of blocks within the northern Ubendian belt, which he believed to represent separate geological entities. Sutton and others (1954) remarked on the intensity of deformation within the belt and on the abundance of mylonitic rocks. They interpreted the belt as a deep seated zone of strike-slip movement.

The occurrence in the Ubendian belt of lithologically and structurally distinct blocks or terranes has been supported by more recent work. Daly and others (1985) established on lithological and structural grounds the presence of eight terranes (Table 1), strongly elongated in a $\mathrm{NW}-\mathrm{SE}$ direction and laterally persistent for up to $400 \mathrm{~km}$. Figure 8 outlines the distribution of the terranes and shows the major shear zones that define their boundaries.

Internally the terranes are heterogenously deformed with extensive tracts of foliated mylonitic and ultra-mylonitic gneisses. In all terranes the main foliation is folded, generally about axes sub-parallel to the elongation of the terrane. Tectonite fabrics within the terranes commonly have a strong $L-S$ fabric. In the Upangwa and Ufipa terranes the extension lineation plunges gently to the $N W$ or $\mathrm{SE}$, parallel to the terrane elongation. However, in the intervening Mbozi terrane the lineation plunges to the ENE$\mathrm{NE}$, and in the Ubende an E to ENE plunge is characteristic, both at a high angle to the terrane elongation. This variation in finite strain orientation compliments the lithological distinction and emphasizes the differences of the terranes. This variation in strain pattern may reflect a component of rotation during emplacement of the terranes. In several of the terranes thrust repetitions are recognized, their movement direction being parallel to the displacement indicated by the linear fabrics.

The Ubendian terranes are bounded by a series of major, steep shear zones, which persist up to $600 \mathrm{~km}$ along strike. The rectilinear trace of the shear zones together with their steep attitude at outcrop suggests that they have a significant vertical dimension. These zones are the structures along which the disparate terranes of the Ubendian belt were juxtaposed. The shear zones comprise a mixture of ductile and brittle fault rocks, varying from ultra-mylonites to gouge, testifying to a long-lived and complex structural history. Stretching lineations from these inter-terrane
Usagaran orogeny to the east. On the basis of similar kinematic data to that used here, Shackleton and Reis (1984) concluded that the Usagaran consists of a series of $\mathrm{NW}-$ directed thrust sheets, overthrust onto the Tanzanian craton. The Ubendian terranes probably developed as a series of tectonic slivers, accreted laterally to the craton during a late stage in this thrusting event, the internal fabrics of the terranes being developed during the Usagaran orogeny. The sub-horizontal linear fabries in the interterrane shear zones together with the internal folding suggests this occurred under a strike-slip to transpressive tectonic regime.

Large sub-horizontal displacements are, again, implied but the mechanism and tectonic setting of this accretion awaits a better understanding of the terranes themselves. However, it does seem clear that the terranes were juxtaposed along a NW-SE trending, strike-slip, transpressive craton margin, at broadly the same time as thrust tectonics were generating the Usagaran belt to the east. Such a mechanism is reminiscent of the Cordilleran tectonics of the northwestern U.S.A. and western Canada (Coney et al., 1980).

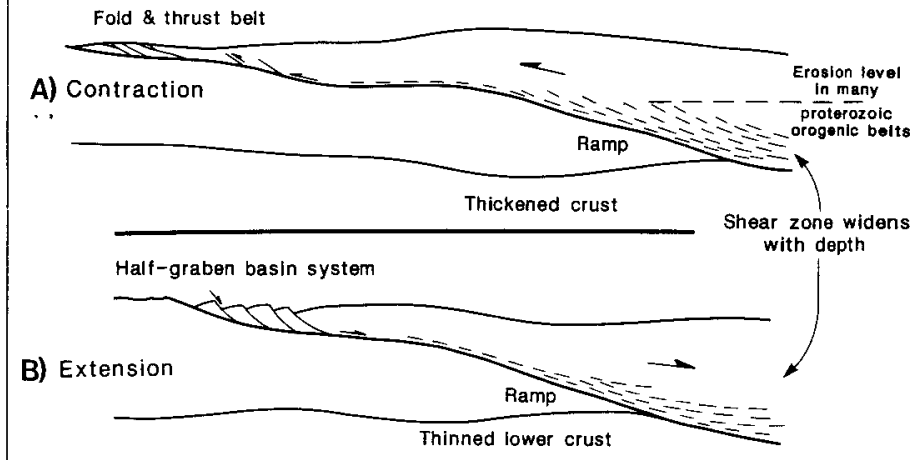

Figure 10: Schematic relationships between shear zones and faults. A - Link between the deep-crustal shear zones and high-level thrust belts. $B-A$ similar geometry suggested for extensional shear zones or "detachments" and their high level expression - asymmetric basins.

\section{Conclusions}

Analysis of ductile shear zones and of the geometry of frontal thrust belts has generated a kinematic data set for the evolution of the Proterozoic orogenic belts of Central Africa. These data independently constrain the interrelationship between orogenic segments and, when combined with the tools of radiometric dating and conventional structural and stratigraphic mapping greatly improve our understanding of Precambrian orogenic sequences. This in turn allows a better understanding of the tectonic processes involved.

The work reviewed here strengthens the conclusion that large horizontal displacements dominated the Proterozoic tectonic evolution of Central Africa. These displacements occurred on major shear zones that link deformation at 
middle and lower crustal levels to that in high-level foreland thrust belts (Fig. 10A). The level of erosion in most Proterozoic orogenic belts results in the extensive exposure of sheared gneisses and a common absence of foreland thrust belts. Such geometric models are supported by deep seismic reflection profiles from other regions where crustalscale ramp-flat geometries have been imaged to link highand low-level deformation zones (Ando et al., 1984).

These Central African shear zones are associated with compressional or strike-slip tectonics. A similar relationship and geometry (Fig. 10B) has been proposed for mid-crust extensional shear zones and high-level basin systems in the Basin and Range Province of the western U.S.A. (Wernicke and Burchfield, 1982). However, to date there is no convincing example of a regionally developed extensional Precambrian shear zone.

The horizontal displacements demonstrated above imply that tectonic models involving dominantly vertical displacements are not supported. However, there still remains a major gap between the recognition of regionally important horizontal tectonics and the tectonic process driving them. The obvious analogue is with plate tectonics, but the recognition of deep crustal plate boundaries and rock assemblages characteristic of them is not easy, and only rarely are Proterozoic plate tectonic interpretations convineing (Hoffman, 1980; Ries et al., 1983). However, kinematic studies such as those reviewed here offer a significant constraint to understanding the tectonic processes of both Proterozoic and Archaean orogeny.

\section{Acknowledgements}

The Luongo work was carried out while the author was employed by the Geological Survey of Zambia, and later supported by the Natural Environment Research Council of the U.K. The Mwenbeshi and Ubendian studies result from participation in Unesco's "Geology for Development" program in Zambia and Tanzania. The author acknowledges discussions with numerous colleagues in Africa and Europe, notably M.P. Coward, J. Klerkx and J.T. Nanyaro. This paper is published by kind permission of the British Petroleum Company.

Dr. M.C. Daly is a member of the BP Structural Studies Group (BP International, Britannic House, Moor Lane, London EC2Y 9BU, U.K.), where he works on basin evolution in terms of regional and plate tectonics. A former regional geologist with the Geological Survey of Zambia, he has participated in several Unescosponsored research projects in sub-Saharan Africa.

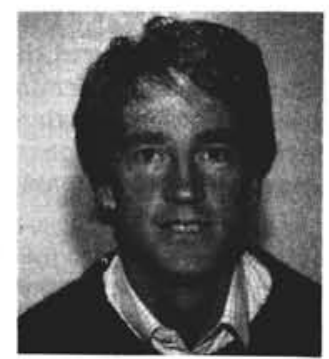

References

Ando, C.J., Czuchra, B.L., Klemperer, S.L., Brown, L.D., Cheadle, M.J., Cook, F.A., Oliver, J.E., Kaufman, S., Walsh, T., Thompson, J.B., Jr., Lyons, J.B. and Rosenfeld, J.L., 1984. Crustal profile of mountain belts: COCOKP deep seismic reflection profiling in New England Appalachians and implications filng in New England Appalachians and implications or architecture of convergent mountain chains. American Association of Petr.
etin, v. 68 , no. 7 , p. $819-837$.

Bally, A.W., Gordy, P.L. and Stewart, G.A., 1966. Structure, seismic data and orogenic evolution of southern Canadian Rocky Mountains. Canadian Petroleum Geology Bulletin, v. 14, no. 3, p. 337 381.

Barr, M.W.C., 1974. The pre-Karroo Geology of the Rufunsa Area, Zambia, with Special Reference to Structure and Metamorphism. Unpublished Ph.D. thesis, University of Leeds.

Boyer, S.E. and Elliott, D., 1982. Thrust systems American Association of Petroleum Geololgists Bulletin, v. 66, no. 9, p. 1196-230.

Briden, J.C., 1976. Application of palaeomagnetism to Proterozoic tectonics. Royal Society of London, Philosophical Transactions Series A, v. 280 no. 1298 , p. $405-416$.

Cahen, L., Snelling, N.J., Delhal, Jr. and Vail, J.R., 1984. The Geochronology and Evolution of Africa. Clarendon Press, Oxford, U.K., 512p.

Cobbold, P.R. and Quinquis, H., 1980. Development of sheath folds in shear regimes. Journal of Structural Geology, v. 2, no. 1/2, p. 119-126.

Coney, P.J., Jones, D.L. and Monger, J.w.H., 1980. Cordilleran suspect terranes. Nature, London, v. 288, p. $329-333$.

Coward, M.P., 1980. Shear zones in the Precambrian crust of southern Africa. Journal of Structurel Geology, v. 2, no. 1/2, p. 19-27.

Coward, M.P. and Daly, M.C., 1984. Crustal lineaments and shear zones in Africa; their relationship to plate movements. Preeambrian Research, v. 24 no. 1 , p. $27-45$.

Dahlstrom, C.D., 1970. Structural geology in the eastern margin of the Canadian Rocky Mountains.
Canadian Petroleum Geology Bulletin, v. 18, no. 3 , p. $332-406$.

Daly, M.C., 1986a. Crustal shear zones and thrus belts: their geometry and continuity in central Africa. Royal Society 2 of London, Philosophicel Transactions Series A, v. 317, na 1539, p. 111-128.

Daly, M.C., 1986b. The tectonic and thermal evolution of the Irumide belt, Zambia. University of Leeds, England, Ph.D. thesis

Daly, M.C., Chakraborty, S.K., Kasolo, P., Musiwa, M., Mumba, P., Naidu, B., Namateba, C., Ngambi, O. and Coward, M.P., 1984. The Lufilian are an Irumide belt of Zambia: results of a geotraverse across their intersection. Journal of African Eart Sciences, v. 2, no. 4, p. 311-318.

Daly, M.C., Klerkx, J. and Nanyaro, J.T., 1985. Early Proterozoic exotic terranes and strike-slip accretion in the Ubendian belt of southwest Tanzania. (Abstract) Terra Cognita, v. 5 , no. $2-3$, p. 257 .

Elliott, D., 1976. The energy balance and deformation mechanisms of thrust sheets. Royal Society of London, Philosophical Transactions Series A, v. 283 no. 1312, p. 289-312.

Hickman, A.C.J., 1978. The Geology of the Bulong Hills Area: Explanation of Degree Sheet No. 143 NW Quarter. Geological Survey of Zambia Report, no. 69 .

Hoffman, P.F., 1980. Wopmay orogen: A Wilson cycle of early Proterozoic age in the northwest of the Canadian Shield. Geological Association of the Canadian Shield. Geological
Canada, Special Paper 20, p. 523-549.

Holmes, A., 1951. The sequence of Pre-cambrian orogenic belts in south and central Africa. $18 \mathrm{t}$ International Geological Congress London, Great Britain, 1948, part 14, p. 254-269.

Kröner, A., 1977. Precambrian mobile belts of southern and eastern Africs, ancient sutures or sites of ensialic mobility? A case for crustal evolution towards plate tectonics. Tectonophysics, v. 40 , no. 1-2, p. 101-1 35 .

McConnell, R.B., 1950. Outline of the Geology of Ufipa and Ubende. Geological Survey of Tanganyika
Platt, J.P. and Vissers, R.L.M., 1980. Extensional structures in anisotropic rocks. Journal of Structural Geology, v. 2, no. 4, p. 397-410.

Ramsay, J.G., 1980. Shear zone geometry: a review. Journal of Structural Geology, v. 2, no. 1-2, p. $83-100$.

Ries, A.C., Shackleton, R.M., Graham, R.H. and Fitches, W.R., 1983. Pan-African structures, ophiolites and melange in the Eastern Desert of Egypt; a traverse at $26^{\circ} \mathrm{N}$. Journal of the Geological Society traverse at $26^{\circ} \mathrm{N}$. Journal of the
of London, v. 140 , no. 1 , p. $75-96$.

Shackleton, R.M., 1973. Correlation of structures across Precambrian orogenic belts in Africa. In: Tarling, D.H. and Runcorn, S.K. (eds.), Implications of Continental Drift to the Earth Sciences, v. 2, part 10. Academic Press, London, p. 1091-1095.

Shackleton, R.M., and Ries, A.C., 1984. The relationship between regionally consistant stretching lineations and plate motions. Journal of Structural Geology, v. 6 , no. 1/2, p. 111-120.

Smith, A.G., 1963. The Geology of the Country around Mazabuka and Kafue: Explanation of Degree Sheets 1527, SE Quarter and 1528, SW Quarter. Geological Survey of Northern ihodesia Report, no. $2,32 p$.

Sutton, J., Watson, J. and James, T.C., 1954. A study of the metamorphic rocks of Karema and Kungwe Bay, western Tanganyika. Geological Survey of Tanganyika Bulletin, no. 22, 70p.

de Swardt, A.M.J., Garrard, P. and Simpson, J.G. 1965. Major zones of transcurrent dislocation and superposition of orogenic belts in parts of central Africa. Geological Society of America Bulletin, Africa. Geological So
v. 76 , no. 1 , p. $89-102$.

Vrana, S., Prasad, R. and Fediukova, E., 1975. Metamorphic kyanite eclogites in the Lufilian are of Zambia. Contributions to Mineralogy and Petrology, v. 51 , no. 2 , p. $139-160$.

Wernicke, B., Burchfiel, B.C. and Williams, P.F., 1982. Modes of extensional tectonies. Journal of Structural Geology, v. 4, no. 2, p. 105-15.

White, S.H., Bretan, P.G. and Rutter, E.ti., 1986. Fault zone reactivation: kinematics and mechanisms. Royal Society of London, Philosophical Transactions Series A, v. 317 , no. 1539, p. 81-92. 